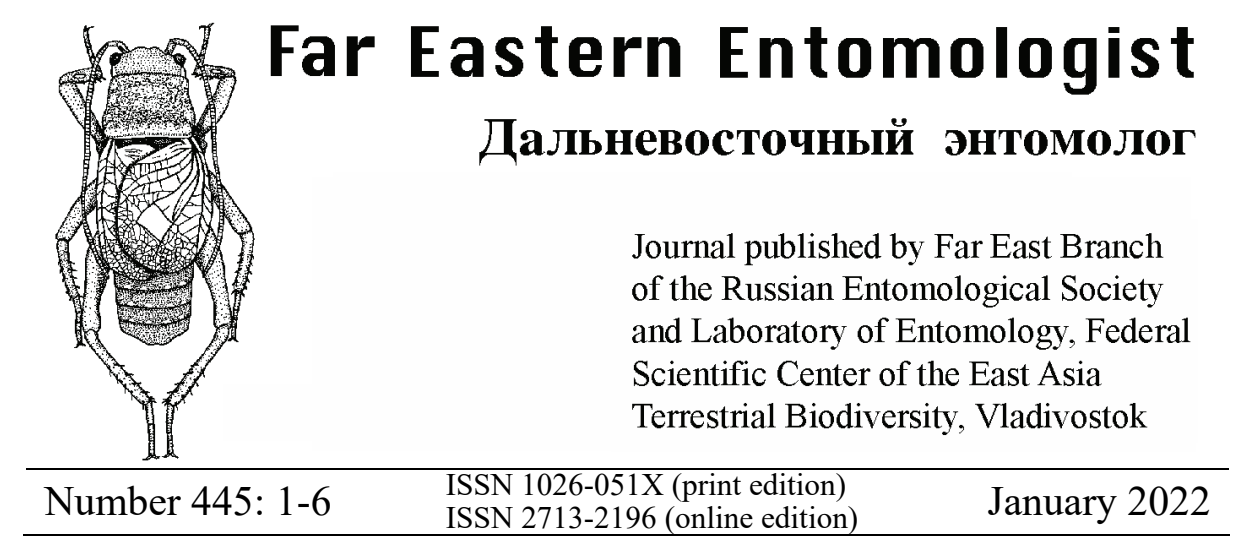

https://doi.org/10.25221/fee.445.1

http://zoobank.org/References/D389215C-9ACC-4D11-8FBA-51E3F1D06B80

\title{
A NEW SPECIES OF THE GENUS CAENORHINUS THOMSON, 1859 (COLEOPTERA: RHYNCHITIDAE) FROM VIETNAM
}

$$
\text { A. A. Legalov }{ }^{1,2,3)}
$$

1) Institute of Systematic and Ecology of Animals, Siberian Branch, Russian Academy of Sciences, Frunze street-11, Novosibirsk 630091, Russia. E-mail: fossilweevils@gmail.com

2) Altai State University, Lenina-61, Barnaul 656049, Russia.

3) Tomsk State University, Lenina Prospekt 36, Tomsk 634050, Russia.

Summary. Caenorhinus (Flavodeporaus) belokobylskii sp. n. is described and illustrated from Northwest Vietnam. The new species is similar to $C$. $(F$.) lobanovi Legalov, 2021 from Laos but differs in the protibiae of males with mucro, longer and thinner rostrum, slender antennae, densely punctate head and pronotum, convex elytral interstriae, brownish-yellow elytra, slightly tapered aedeagus, and armament of the endophallus.

Key words: Curculionoidea, Deporaini, Flavodeporaus, taxonomy, new species, Oriental Region.

А. А. Легалов. Новый вид рода Caenorhinus Thomson, 1859 (Coleoptera: Rhynchitidae) из Вьетнама // Дальневосточный энтомолог. 2022. N 445. C. 16.

Резюме. Из Северо-Западного Вьетнама описан Caenorhinus (Flavodeporaus) belokobylskii sp. n., который отличается $C$. (F.) lobanovi Legalov, 2021 из Лаоса передними голенями самцов с мукро, более узкой и длинной головотрубкой, 
стройными усиками, густо пунктированными головой и переднеспинкой, выпуклыми промежутками надкрылий, коричневато-желтыми надкрыльями, слабо заостренным эдеагусом и вооружением эндофаллуса.

\section{INTRODUCTION}

The genus Caenorhinus Thomson, 1859 is the largest genus in this tribe Deporaini includes more than 140 described species and distributed in the Holarctic and Oriental Regions. This genus is characterized by the 9th striae merge with the 10th striae near the middle of the elytra, the distinct neck and slightly widened and weakly flattened rostrum (Legalov, 2007). Thirteen subgenera belong to the Caenorhinus. The subgenus Flavodeporaus Legalov, 2007 is characterized by the elytra without metallic lustre, not compact antennal club, the metacoxa of males without tooth, strongly convex eyes, usually yellow body and the ventrite 5 of males without a depression and teeth on each side. Flavodeporaus included 50 described species from South-eastern China, Korea, Japan, Eastern and South India, Sri Lanka, Myanmar, Vietnam, Laos, Thailand, Java, Sumatra, Kalimantan, Sulawesi, and the Philippines (Legalov, 2007, 2020a, 2020b). Eighteen species of the genus Caenorhinus, including ten species of Flavodeporaus, were known from Vietnam. In this paper, the new species of this subgenus from North Vietnam is described.

\section{MATERIAL AND METHODS}

The type specimens are kept in the ZIN = Zoological Institute RAS (Russia: Sankt-Petersburg) and ISEA = Institute of Systematic and Ecology of Animals (Russia: Novosibirsk). Descriptions, body measuring, and photographs were performed using the Zeiss Stemi 2000-C dissecting stereomicroscope. The terminology of weevil body is according to Legalov (2007) and Lawrence et al. (2010).

\section{TAXONOMY}

\section{Genus Caenorhinus Thomson, 1859}

Subgenus Flavodeporaus Legalov, 2007

Caenorhinus (Flavodeporaus) belokobylskii Legalov, sp. $\mathbf{n}$.

http://zoobank.org/NomenclaturalActs/9356A246-3CB8-4DBB-8D0C-7215F82BF380

Figs 1-6

TYPE MATERIAL. Holotype - $\widehat{\jmath}$, Vietnam: Hòa Bình Province, Yên Thủy District, Đa Phúc, $20^{\circ} 18^{\prime} \mathrm{N}, 105^{\circ} 35^{\prime} \mathrm{E}, \mathrm{h}=100 \mathrm{~m}, 3-4 . \mathrm{V}$ 2002, S. Belokobylskij (ZIN). Paratypes: the same label as holotype, 1ㅇ, $1 \delta^{\Uparrow}(\mathrm{ZIN})$; Hòa Bình Province, Yên Thủy District, Cuc Phuong National Park (Vườn Quốc Gia Cúc Phương), $20^{\circ} 23^{\prime} \mathrm{N}, 105^{\circ} 34^{\prime} \mathrm{E}, \mathrm{h}=300 \mathrm{~m}, 5-6 . \mathrm{V} 2002,1{ }^{\Uparrow}$, S. Belokobylskij (ISEA). 
DESCRIPTION. Body brownish-yellow, covered with decumbent light coloured hairs. Antennae dark-brown. Rostrum, head, sides of pronotum brown.

MALE. Body length (without rostrum) 3.8-4.3 mm. Rostrum length 0.8-0.9 mm. Rostrum subequal in length or slightly shorter than pronotum, 2.5-2.6 times as long as wide at apex, 3.8-3.9 times as long as wide at middle and 2.9-3.0 times as long as wide at base, slightly curved, distinctly expanded to apex, weakly flattened, subglabrous in apical part, coarsely punctate in basal part. Eyes large, strongly convex, suboval, finely faceted. Forehead weakly impressed, 1.2-1.4 times as wide as width of rostrum basally, finely punctate. Temples quite long, $0.6-0.7$ times as long as eye. Vertex convex, densely punctate. Head narrowed behind eyes. Neck well defined, transversely wrinkled. Antennae slender, inserted behind middle of rostrum, extend middle of pronotum. Antennomeres 1 and 2 long-oval, equal in length. Antennomere 12.0 times as long as wide in apex. Antennomeres 2-8 subconical. Antennomeres 3 5 equal in length. Antennomeres 3-8 subequal in width. Antennomere 32.8 times as long as wide, 1.2 times as long as and 0.8 times as narrow as antennomere 2 . Antennomere 62.6 times as long as wide, 0.9 times as long as antennomere 5. Antennomeres 7 and 8 equal in length. Antennomere 72.4 times as long as wide, 0.9 times as long as antennomere 6 . Antennal club strongly not compact, 0.6 times as long as antennomeres 2-8 combined. Antennomeres 9 and 10 equal in length. Antennomere 91.8 times as long as wide, 1.5 times as long as and 2.0 times as narrow as antennomere 8 .

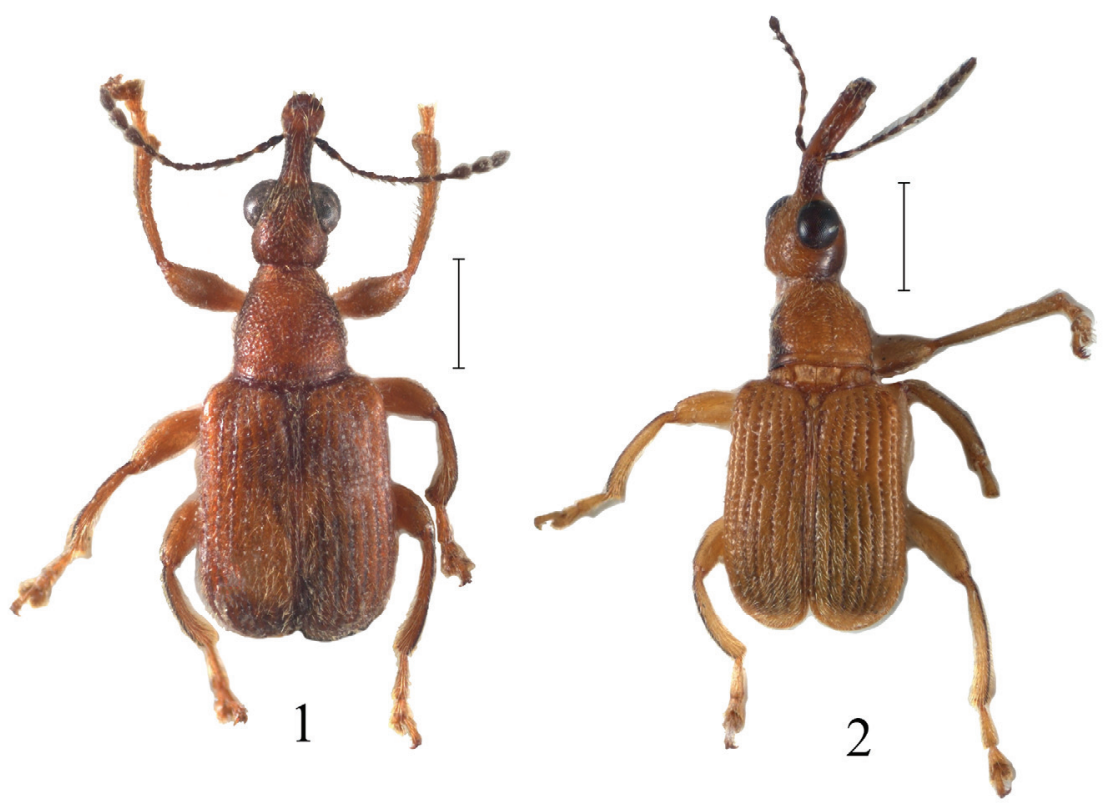

Figs 1, 2. Caenorhinus (Flavodeporaus) belokobylskii sp. n., habitus, dorsal view: 1 holotype, male; 2 - paratype, female. Scale bar $1.0 \mathrm{~mm}$. 
Antennomere 101.5 times as long as wide, 1.2 times as wide as antennomere 9. Antennomere 112.0 times as long as wide, 1.1 times as long as and 0.8 times as narrow as antennomere 10. Pronotum campanulate, 1.6-1.7 times as long as wide at apex, 1.1 times as long as wide in middle and subequal to wide at base. Disk weakly convex, densely punctate. Scutellum trapezoid, finely punctate. Elytra 1.5 times as long as wide at base, 1.3-1.5 times as long as wide at middle, 1.5-1.6 times as long as wide at apical fourth, 2.2-2.3 times as long as pronotum, without metallic lustre. Humeri slightly flattened. Elytral striae distinct. Scutellar striole absent. Stria 9 full, merging with stria 10 near metacoxa. Interstriae convex, 4.0-5.0 times as wide as elytral stria, finely punctate. Prosternum finely punctate. Pre- and postcoxal portions of prosternum short. Procoxal cavities contiguous. Metanepisternum 3.2 times as
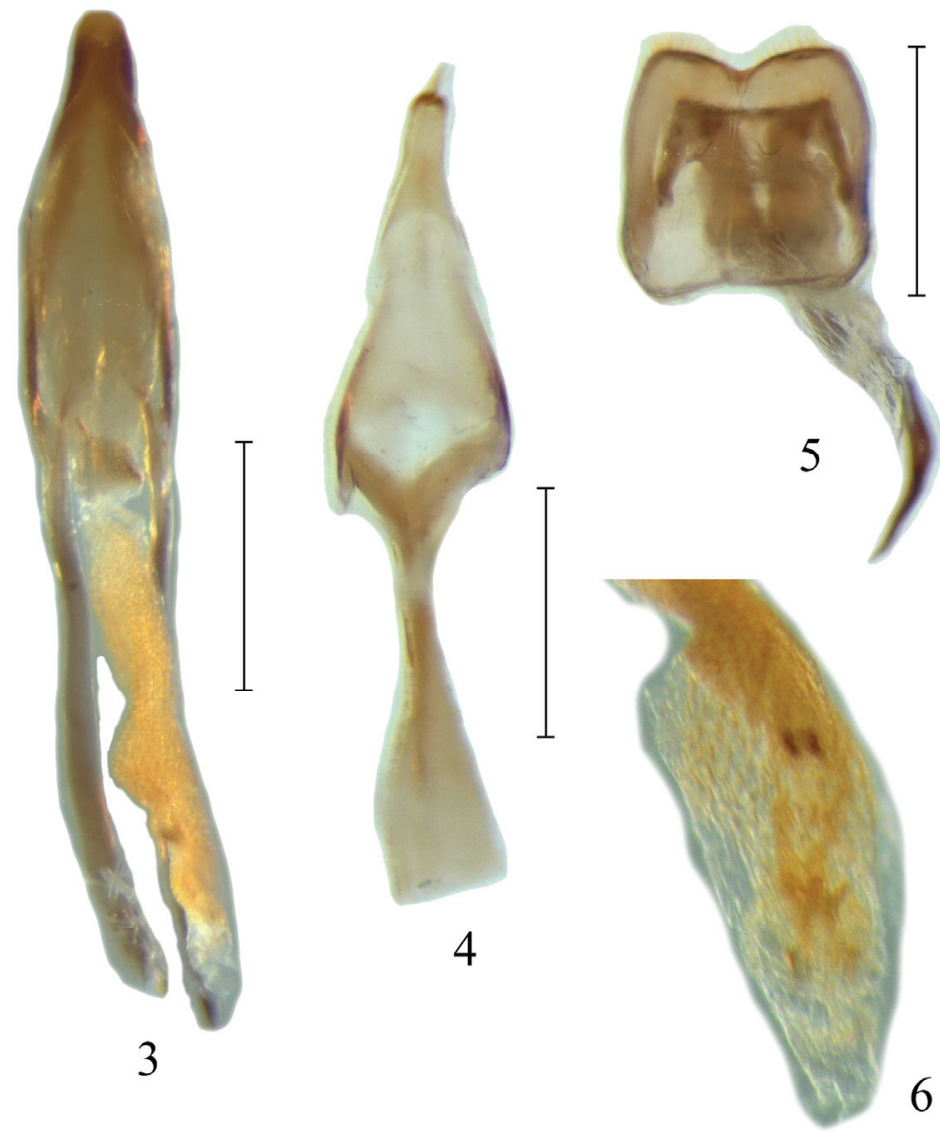

Figs. 3-6. Caenorhinus (Flavodeporaus) belokobylskii sp. n., genitalia, dorsal view: 3 aedeagus; 4 - tegmen; 5 - tergite $8 ; 6$ - armament of endophallus. Scale bar $1.0 \mathrm{~mm}$ for figs $3-5$. 
long as wide, finely punctate. Metaventrite about 1.3 times as long as length of metacoxa, weakly convex, finely punctate. Abdomen convex, punctate. Ventrites 1 and 2 fused. Ventrite 1 about 0.5 times as long as length of metacoxa. Ventrite 22.0 times as long as ventrite 1 . Ventrite 30.8 times as long as ventrite 2 . Ventrite 4 subequal to ventrite 3 . Ventrite 51.4 times as long as ventrite 4 , without depression and teeth on each side. Part of propygidium and pygidium exposed. Procoxae large, conical. Metacoxae transverse, without tooth. Femora weakly thickened, with costate dorsal margin in apical one third. Tibiae almost straight, flattened, with costate dorsal margin. Protibiae with mucro. Tarsi long. Tarsomere 1 long-conical. Tarsomere 2 wide-conical. Tarsomere 3 bilobed. Tarsomere 5 elongate. Tarsal claws divergent and dentate.

Armament of endophallus sclerotized (Fig. 6).

FEMALE. Body length (without rostrum) $3.8 \mathrm{~mm}$. Rostrum length $1.2 \mathrm{~mm}$. Rostrum curved in place of antennal attachment, about 1.2 times as long as pronotum, 3.2 times as long as wide at apex, 4.5 times as long as wide at middle and 4.2 times as long as wide at base, subglabrous from apex to place of antennal attachment. Forehead 1.4 times as wide as width of rostrum basally. Temples subequal in length to eye. Antennae inserted before middle of rostrum. Antennal club 0.5 times as long as antennomeres 2-8 combined. Antennomere 92.3 times as long as wide, 1.3 times as long as and 1.4 times as narrow as antennomere 8. Antennomere 101.8 times as long as wide, 0.9 times as long as, 1.1 times as wide as antennomere 9 . Antennomere 112.4 times as long as wide, 1.2 times as long as and 0.9 times as narrow as antennomere 10. Pronotum 1.7 times as long as wide at apex, 1.1 times as long as wide in middle and subequal to wide at base. Elytra 1.5 times as long as wide at base, 1.4 times as long as wide at middle, 1.3 times as long as wide at apical fourth, 2.3 times as long as pronotum. Metaventrite about 1.6 times as long as length of metacoxa. Ventrite 10.6 times as long as length of metacoxa. Ventrite 21.5 times as long as ventrite 1 . Ventrite 30.8 times as long as ventrite 2 . Ventrite 40.6 times as long as ventrite 3 . Ventrite 51.3 times as long as ventrite 4 . Tibiae without mucro.

COMPARISION. The new species is similar to $C$. (F.) lobanovi Legalov, 2021 from Laos but differs from the latter in the protibiae of males with mucro, longer and thinner rostrum, slender antennae, densely punctate head and pronotum, convex elytral interstriae, brownish-yellow elytra, slightly tapered aedeagus, and armament of the endophallus.

DISTRIBUTION. NW Vietnam: Hòa Bình Province.

ETYMOLOGY. The species is named in honor of Dr. Sergey A. Belokobylskij (Sankt-Petersburg), who collected this species.

\section{ACKNOWLEDGEMENTS}

The author thanks O. Jaeger (Germany: Dresden), K.- D. Klass (Germany: Dresden), B.A. Korotyaev (Russia: Sankt-Petersburg) and R. Dunda (Czech Republic: Prague) for the opportunity to study of material of the genus Caenorhinus deposited 
in the Senckenberg Naturhistorische Sammlungen Dresden, Universität Hamburg, National Museum of Natural History (Czech Republic: Prague), and Zoological Institute RAS (Sankt-Petersburg).

\section{REFERENCES}

Lawrence, J.F., Beutel, R.G., Leschen, R.A.B. \& Slipinsky, S.A. 2010. Chapter 2. Glossary of Morphological Terms. P. 9-20. In: Handbook of Zoology. Arthropoda: Insecta. Tb. 40: Coleoptera (Beetles). Vol. 2: Morphology and Systematic (Elateroidea, Bostrichformia, Cucujiformia partim). De Gruyter, Berlin and Boston.

Legalov, A.A. 2007. Leaf-rolling weevils (Coleoptera: Rhynchitidae, Attelabidae) of the world fauna. Agro-Siberia, Novosibirsk. 523 pp.

Legalov, A.A. 2021a. A new species of the genus Caenorhinus Thomson, 1859 (Coleoptera, Rhynchitidae) from Laos. Ecologica Montenegrina, 41: 36-39. DOI: 10.37828/em.2021.41.6

Legalov, A.A. 2021b. Caenorhinus lobanovi, a new species of the tribe Deporaini (Coleoptera, Rhynchitidae) from Laos. Caucasian Entomological Bulletin, 17(1): 219221. [In Russian] DOI: 10.23885/181433262021171-219221 